\title{
RAMAN SPECTROSCOPY OF VIBRATIONAL AND ROTATIONAL RELAXATION OF ACETONITRILE MOLECULES DISSOLVED IN IONIC LIQUIDS *
}

\author{
V. Aleksa ${ }^{a}$, V. Barkauskas ${ }^{\text {a }}$, V. Pogorelov ${ }^{\mathrm{b}}, \mathrm{H}$. Fuess $^{\mathrm{c}}$, and V. Balevičius ${ }^{\mathrm{a}}$ \\ ${ }^{a}$ Faculty of Physics, Vilnius University, Saulettekio 9, LT-10222 Vilnius, Lithuania \\ E-mail: valdemaras.aleksa@ff.vu.lt, vytenis.barkauskas@ff.vu.lt, vytautas.balevicius@ $\mathrm{ff} . v u . l t$ \\ ${ }^{\mathrm{b}}$ Faculty of Physics, Kyiv National Taras Shevchenko University, Glushkova Ave 2 build. 1, UA-03022 Kyiv, Ukraine \\ E-mail: pogorelov@univ.kiev.ua \\ ${ }^{\mathrm{c}}$ Fachbereich Materialwissenschaft, University of Technology Darmstadt, Petersenstr. 23, D-64287 Darmstadt, Germany \\ E-mail: hfuess@tu-darmstadt.de
}

Received 8 October 2007; revised 31 October 2007; accepted 21 November 2007

\begin{abstract}
Vibrational and rotational relaxation processes of acetonitrile (AN) molecules as molecular probes dissolved in the imidazolium-based room-temperature ionic liquid (RTIL) 1-decyl-3-methyl-imidazolium bromide have been studied by Raman spectroscopy technique (the band shape analysis using different polarizations of the incident and scattered light). It has been shown that the vibrational relaxation processes are quickened in the RTIL surrounding. The corresponding vibrational correlation times decrease from about $3 \mathrm{ps}$ in the neat AN to 1.5-2 ps in AN solution in RTIL (10 and $20 \mathrm{wt} \%$ of AN). The effect of RTIL environment on the rotational dynamics of AN, namely, on the tumbling motion of dipole moments, is rather small. However, the slow-down of AN reorientations in RTIL was distinguished, namely, the rotational correlation times increase from 1.0-1.5 ps (neat AN) to 1.6-1.9 ps (AN/RTIL solutions). The results have been discussed in terms of various molecular and media contributions to these processes (H-bonding, highly viscous media effect, intermode exchange of vibrational energy, etc). The demolition of structural effects (short-range order and mesoscopic structures in the nano-scale) in 1-decyl-3-methyl-imidazolium bromide by the mutual penetration of AN and RTIL species is suspected.
\end{abstract}

Keywords: properties of molecules and molecular ions, line and band widths, shapes and shifts, ionic liquids

PACS: $33.15 .-\mathrm{e}$, 33.70.Jg

\section{Introduction}

Ionic liquids (ILs) are one of the red-hot and most successful breakthroughs in creating multifunctional materials. ILs have already demonstrated their unique features in many fields of high technology. Particularly notable are enzyme catalysis, protein synthesis, membrane technology, battery and fuel cells, dyesensitized solar cells (DSSC), gas sensors, nanotechnology, etc (see Refs. [1-3] and the literature therein). Nevertheless in this wealth of work certain important gaps remain. Namely, investigations of the fundamental molecular processes, such as conformational transitions, phase separation, proton transfer, vibrational and rotational relaxations occurring in various IL environments. Note that due to their dielectric properties (static dielectric constants of various classes of ILs

\footnotetext{
* The report presented at the 37th Lithuanian National Physics Conference, 11-13 June 2007, Vilnius, Lithuania.
}

are spread usually over $11-14[4,5])$ the IL systems are not 'super-polar'. Their extraordinary action in certain chemical reactions and in other molecular processes is mainly due to supra-molecular structuring in nanoscale effects and possible equilibria within the IL phase [3]. Hence, understanding of the peculiar role of ILs as solvents is not possible without understanding their microscopic properties, e. g. short-range ordering, microscopic friction effects, etc. These can be studied by the micro-dynamics of molecular probes, i. e. measuring correlation times of vibrational and rotational relaxation of spherical (neopentane, tetramethylsilane, etc) or symmetrical top (acetonitrile, chloroform, etc) molecules dissolved in various IL systems. Since those processes run at ordinary conditions in the time scale of picoseconds, a Raman spectroscopy technique (the band shape analysis using different polarizations of the incident and scattered light, i.e. isotropic and 


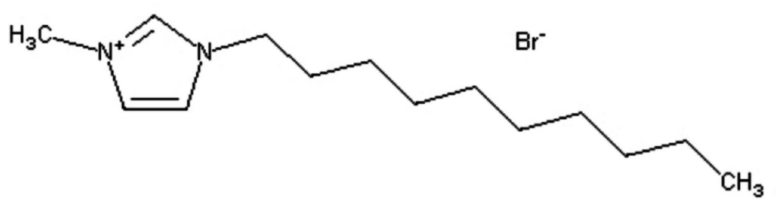

Fig. 1. 1-decyl-3-methyl-imidazolium bromide.

anisotropic band shape analysis $[6,7])$ can be successfully exploited.

The purpose of the present work was investigation of vibrational and rotational relaxation processes of acetonitrile molecules as molecular probe dissolved in the room-temperature ionic liquid 1-decyl-3-methylimidazolium bromide by Raman spectroscopy.

\section{Experiment}

Commercially available 1-decyl-3-methyl-imidazolium bromide (abbreviation: aha2/cdi16, CAS Nr 188589-32-4, Fig. 1) of $\geq 98 \%$ purity from Merck KGaA Darmstadt and acetonitrile (AN) of high purity $(99.5+\%)$ from Aldrich Chemical Co were used in the present work without additional purification. The samples were prepared by weighing $( \pm 0.1 \mathrm{mg})$ the components.

Raman spectra were recorded using a DFS-12 double-grating spectrometer with a slit width of $0.08 \mathrm{~mm}$. Similarly as in [8], this value of the slit width was found to be optimal. Namely, registration of the weakest Raman bands was still possible at this setting, whereas the instrumental broadening of the observed bandwidth could be neglected. The excitation source was an argon-ion laser (Stabilite, SpectraPhysics) operating at $488.0 \mathrm{~nm}(120 \mathrm{~mW})$ or $514.5 \mathrm{~nm}(120 \mathrm{~mW})$. All measurements were carried out at the $90^{\circ}$ scattering geometry. The required polarization of the incident and scattered light was selected by a conventional polarizer. The detection part of the instrument consists of photo-multiplier and a photon-counting system online with a standard PC. The Raman spectra band shapes were processed digitally using the Microcal Origin [9] program package.

\section{Results and discussion}

We have chosen for the present study one of imidazolium-based room temperature ionic liquids (RTILs), namely - 1-decyl-3-methyl-imidazolium bromide. This substance has a rather low melting point $(289 \mathrm{~K})$ and is totally miscible with water and acetonitrile. Perhaps it is the most intriguing that just above its melt-

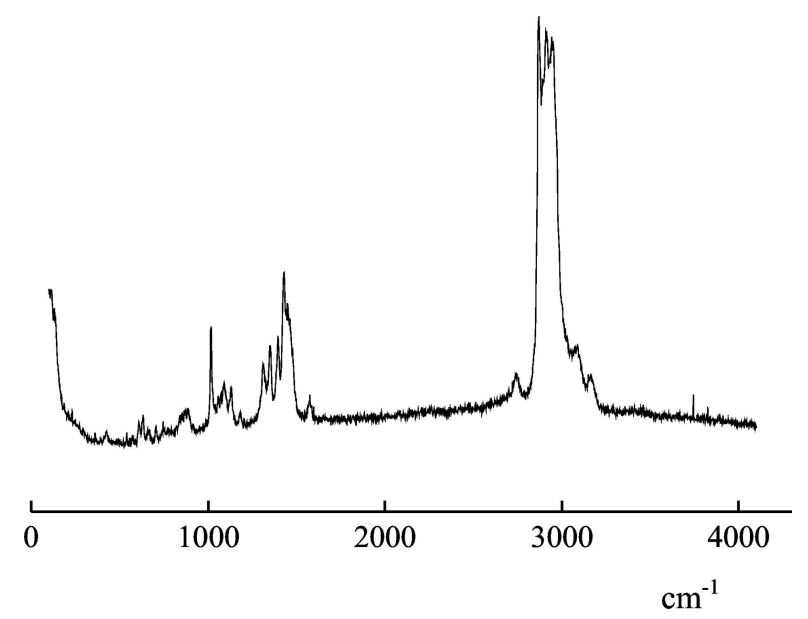

Fig. 2. Raman spectrum of neat 1-decyl-3-methyl-imidazolium bromide in $100-4000 \mathrm{~cm}^{-1}$ range at $T=295 \mathrm{~K}$.

ing point 1-decyl-3-methyl-imidazolium bromide is extremely viscous $\left(7892.9 \mathrm{~mm}^{2} / \mathrm{s}\right.$ at $293 \mathrm{~K}$, all data from Merck KGaA [1]). Thus an extreme frictional action and hence a peculiar dynamics of solute molecules may be expected in this RTIL as a solvent.

The Raman spectrum of 1-decyl-3-methyl-imidazolium bromide is shown in Fig. 2. Several free spectral 'windows' are easily noticeable, namely below about $600 \mathrm{~cm}^{-1}$, rather narrow spots at 900 and $1200 \mathrm{~cm}^{-1}$, and a very broad region between 1500 and $2900 \mathrm{~cm}^{-1}$ that can be used analysing the band shapes of properly chosen probe molecules.

The symmetrical top molecules of acetonitrile were chosen as the probes in the present work for several serious reasons. First of all the rotational and translational dynamics of acetonitrile molecules in the neat AN as well as in various solvents have been studied using a wide kit of experimental techniques (FTIR, Raman, NMR relaxations, etc, see $[8,10-12]$ and the references therein). These data are very useful for comparative and metrological purposes. Furthermore, Raman bands $\nu 2\left(2249 \mathrm{~cm}^{-1}\right)$ and $\nu 4\left(918 \mathrm{~cm}^{-1}\right)$ usually used in those studies fit into the free spectral 'windows' of 1-decyl-3-methyl-imidazolium bromide (Fig. 2). Also note that AN molecules were successfully used probing reorientational motion in polyacrylamide gels [13].

The Raman band shape analysis of these AN modes ( $\nu 2$ and $\nu 4, \mathrm{C}_{3 \mathrm{v}}$ point group symmetry and both modes of $\mathrm{A}_{1}$ type) is convenient also from the theoretical point of view. Namely, starting from a quite general treatment $[6,7]$, the isotropic and anisotropic profiles of $\mathrm{Ra}-$ man spectra $I_{\text {iso }}(\omega)$ and $I_{\text {anis }}(\omega)$ are related to the experimental shapes in VV and VH scattering geometry, 


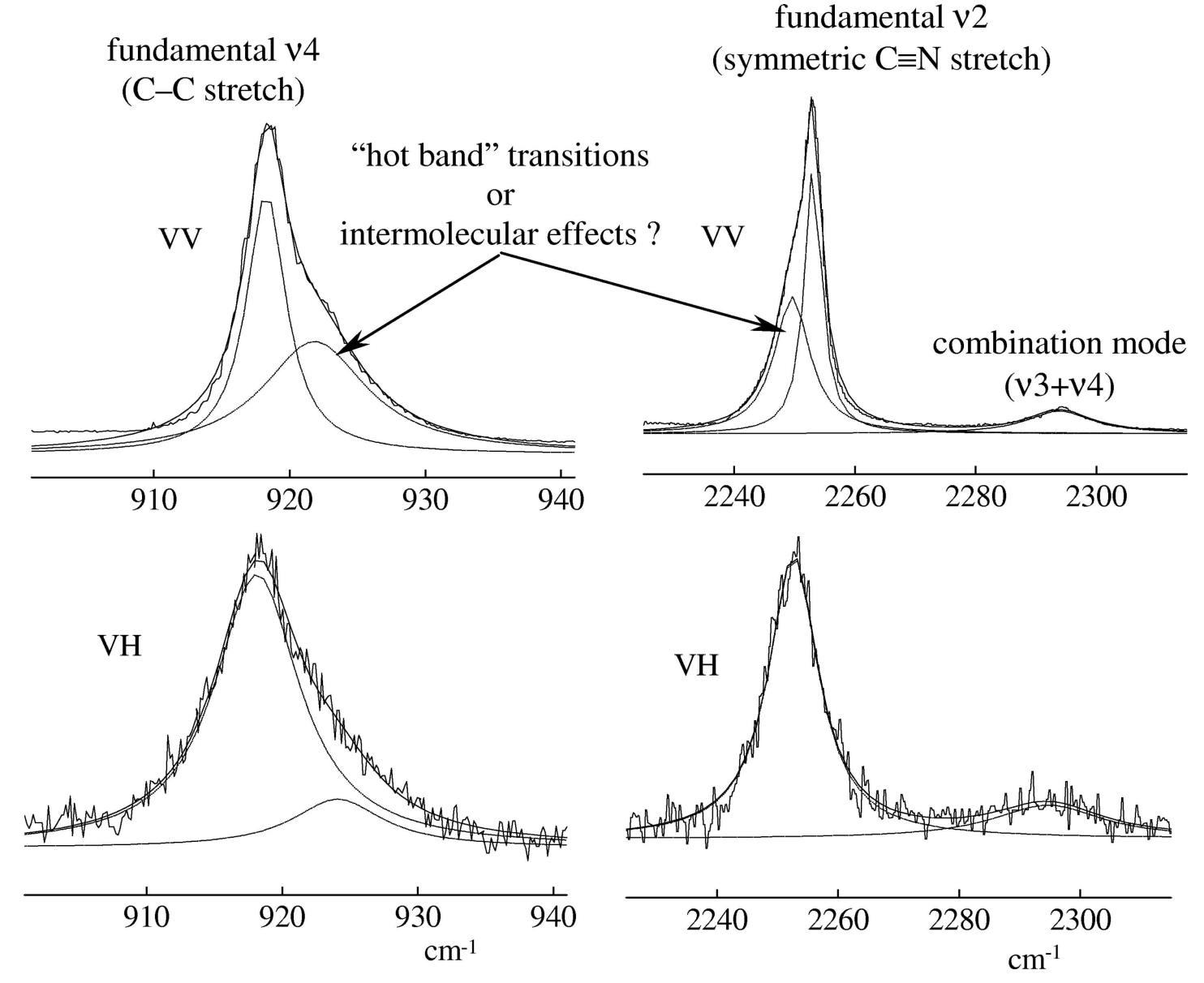

fundamental $v 2$

(symmetric $\mathrm{C} \equiv \mathrm{N}$ stretch)

Fig. 3. Raman spectra (VV and VH) of neat $\mathrm{AN}$ in the ranges of modes $\nu 2\left(2249 \mathrm{~cm}^{-1}\right)$ and $\nu 4\left(918 \mathrm{~cm}^{-1}\right)$.

$I_{\mathrm{VV}}(\omega)$ and $I_{\mathrm{VH}}(\omega)$ respectively, via their convolution with the instrumental function $A(\omega)$ as

$$
\begin{aligned}
I_{\mathrm{VV}}-\frac{4}{3} I_{\mathrm{VH}} & =A \otimes I_{\text {iso }}, \\
I_{\mathrm{VH}} & =A \otimes I_{\text {anis }} .
\end{aligned}
$$

If the slit widths are set properly, and thus instrumental disturbances of the band shapes can be neglected, and if the contours appear during processing to be Lorentzians having half-widths at half heights (HWHH) $\Delta$, the corresponding vibrational and rotational correlation times are calculated simply:

$$
\tau_{\mathrm{vib}}=\frac{1}{2 \pi c \Delta_{\text {iso }}} \quad \text { and } \quad \tau_{\text {rot }}=\frac{1}{2 \pi c\left(\Delta_{\text {anis }}-\Delta_{\text {iso }}\right)}
$$

The information on the rotational dynamics obtained analysing $\tau_{\text {rot }}$ in the case of $\mathrm{AN}$ (i.e. $\mathrm{C}_{3 \mathrm{v}}$ point group symmetry and $\mathrm{A}_{1}$ mode) allows of a quite obvious interpretation. Applying the symmetry considerations [7], the rotational correlation functions can be expressed via single stochastically averaged Wigner $D$ function:

$$
C^{\mathrm{rot}}(t)=\left\langle D_{00}^{2}(\delta \Omega(t))\right\rangle=\left\langle 3 \cos ^{2}(\beta(t))-1\right\rangle,
$$

where $\delta \Omega(t)$ is the set of Eulerian angles that the molecule-fixed coordinate system (MCS) reorients after $t \mathrm{~s}$ with respect to the laboratory-fixed coordinate system (LCS) and $\beta$ is the polar angle of the principal symmetry axis of the molecule with respect to the LCS. It means that $\tau_{\text {rot }}$ obtained from the band shapes of $\nu 2$ and $\nu 4$ modes characterizes the tumbling motion (only $\beta$ changes) of AN molecules.

The Raman spectra (VV and VH) of the neat AN in the regions of $\nu 2\left(2249 \mathrm{~cm}^{-1}\right)$ and $\nu 4\left(918 \mathrm{~cm}^{-1}\right)$ modes are shown in Fig. 3. Secondary band structures, noted and considered in some earlier studies $[9,11,13]$, are observed at the present instrumental setting as well. Asymmetric shoulders are attributed in some works to the "hot bands" [13], whereas in others $[8,10]$ those extra bands are believed to originate from intermolecular effects (aggregation of AN or H-bonding with solvent molecules). Without getting deep into polemic at 
Table 1. Measured half-widths (HWHH) of Raman modes $\nu 2$ and $\nu 4$ and calculated vibrational and rotational correlation times $\left(\tau_{\text {vib }}\right.$ and $\left.\tau_{\text {rot }}\right)$ in neat AN at $T=295 \mathrm{~K}$ and in AN solution in 1-decyl-3-methyl-imidazolium bromide (10 and $20 \mathrm{wt} \%$ of $\mathrm{AN})$. Available literature data are given for comparison.

\begin{tabular}{|c|c|c|c|c|}
\hline & $\Delta_{V V}, \mathrm{~cm}^{-1}$ & $\Delta_{V H}, \mathrm{~cm}^{-1}$ & $\tau_{\text {vib }}, \mathrm{ps}$ & $\tau_{\mathrm{vib}}, \mathrm{ps}$ \\
\hline \multicolumn{5}{|c|}{ neat $\mathbf{A N}$} \\
\hline \multirow[t]{5}{*}{$\nu 2$} & $1.65 \pm 0.08$ & $6.10 \pm 0.97$ & 3.2 & 1.2 \\
\hline & $2.0 \pm 0.1[11]$ & $7.2 \pm 0.5[11]$ & 2.7 & 1.0 \\
\hline & $1.6 \pm 0.17[8]$ & - & 3.3 & - \\
\hline & $1.83 \pm 0.18[12]$ & $6.77 \pm 0.25[12]$ & 2.9 & 1.1 \\
\hline & $3.0[10]$ & $7.3[10]$ & 2.5 & 1.3 \\
\hline \multirow[t]{3}{*}{$\nu 4$} & $1.5 \pm 0.1$ & $4.9 \pm 0.9$ & 3.5 & 1.6 \\
\hline & $1.5 \pm 0.1[11]$ & $6.4 \pm 0.7[11]$ & 3.5 & 1.1 \\
\hline & $1.2 \pm 0.17[8]$ & - & 4.4 & - \\
\hline \multicolumn{5}{|c|}{ AN solution in 1-decyl-3-methyl-imidazolium bromide* } \\
\hline \multirow[t]{2}{*}{$\nu 2,10 \%$} & $3.4(3.4)^{* *}$ & $6.4(-)^{* *}$ & $1.6(1.6)$ & $1.8(-)$ \\
\hline & $4.4(4.8)^{* * *}$ & & & \\
\hline \multirow[t]{2}{*}{$20 \%$} & $3.5(2.7)$ & $6.3(6.7)$ & $1.5(2.0)$ & $1.9(1.3)$ \\
\hline & $4.8(4.9)^{* * *}$ & & & \\
\hline$\nu 4,10 \%$ & $2.7(3.1)$ & $-(-)$ & $2.0(1.7)$ & $-(-)$ \\
\hline $20 \%$ & $2.4(2.6)$ & $6.0(6.1)$ & $2.2(2.0)$ & $1.5(1.5)$ \\
\hline
\end{tabular}

* measured at 295 and $329 \mathrm{~K}$ (in parentheses).

** the errors, after a nonlinear curve fitting procedure by Lorentz functions [9] was applied, and the extra bands were removed from the fundamentals (Figs. 3-5), do not exceed $10 \%$ for $\mathrm{VV}$ and about $20 \%$ for VH contours.

*** fit results using a single Lorentz contour given for comparison.

the present stage of work, i. e. before starting on AN dynamics in IL environment, it is only important to note that the half-widths and the values of $\tau_{\mathrm{vib}}$ and $\tau_{\text {rot }}$ (2) obtained by digital processing of $\nu 2$ and $\nu 4$ band profiles pertain well to the data available in literature. They are collected in Table 1. Hence, the instrumental settings used in this study (see Sec. 2) are likely to be 'metrologically' approved.

Some of the experimental Raman contours of AN dissolved in 1-decyl-3-methyl-imidazolium bromide are shown in Figs. 4 and 5. The measured half-widths (HWHH) of Raman modes $\nu 2$ and $\nu 4$ and calculated vibrational and rotational correlation times $\left(\tau_{\text {vib }}\right.$ and $\tau_{\text {rot }}$ ) at $T=295$ and $329 \mathrm{~K}$ are given in Table 1 . Unfortunately the dilution of $10 \mathrm{wt} \%$ of AN was too strong to extract the shapes of $\nu 4$ mode in $\mathrm{VH}$ polarization from the noise. The same happened with the $\nu 2$ contour at the higher temperature.

Secondary structures of the $\nu 2$ and $\nu 4$ Raman bands seen in the neat AN (Fig. 3) disappear in certain solutions, e.g. in water, formic acid, water/polymer gels $[10,13]$. With increasing dissolution the overlap of bands increases, the sum-contour loses the asymmetry, and in the sequel the overlapping band com- ponents can not be resolved by statistical processing using least-squares fitting procedures [13]. However, more or less pronounced secondary structure of these bands is preserved in the investigated AN / IL solutions (Figs. 4 and 5). The VV spectra of $\nu 2$ and $\nu 4$ modes were fitted to the sum of two Lorentz profiles using the nonlinear regression method based on the LevenbergMarquardt algorithm [9]. An enrolment of the second Lorentz function into a fitting procedure led to significant improvements of the statistical parameters $\chi^{2}$ (the square deviation) and $R^{2}$ (the correlation coefficient). Some of those cases are demonstrated in Figs. 4 and 5. The convergence to the same values of contour parameters (maximum position, $\mathrm{HWHH}$, etc) independently of their initial values (zero-order approach) was achieved practically in all cases. Unstable fit was met for $10 \%$ solution at the lower temperature (i. e. $295 \mathrm{~K}$ ) only. The overlap of VV contours at these conditions indeed seems to be too strong to allow to resolve them. The band fitting with a single Lorentz function gave overestimated HWHH value (Table 1) that differed from the true widths sufficiently. Therefore an approximate value of $\Delta_{\mathrm{VV}}=3.4 \mathrm{~cm}^{-1}$, i. e. the same as in $20 \%$ solution (Fig. 4), was used in the calculation of $\tau_{\text {vib }}$ and 


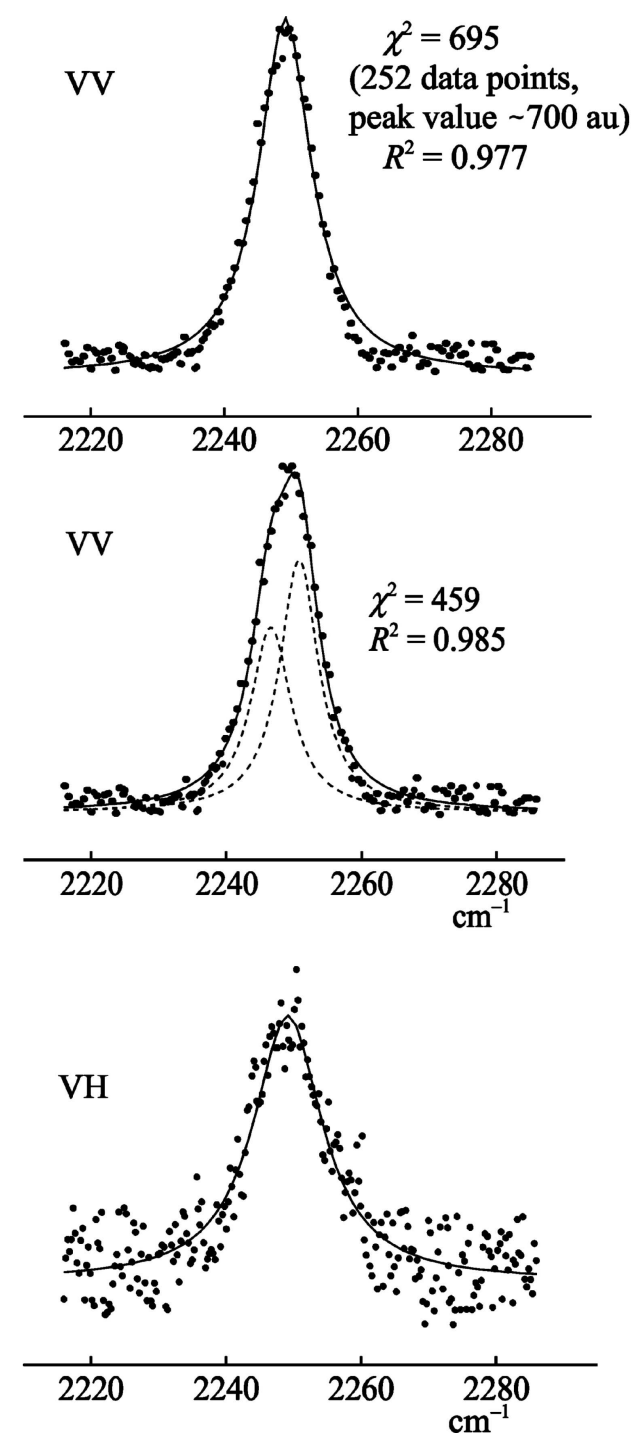

Fig. 4. Raman VV and VH contours of the $\nu 2$ mode of AN at $20 \mathrm{wt} \%$ dilution in 1-decyl-3-methyl-imidazolium bromide ( $T=$ $295 \mathrm{~K}$ ) processed by the nonlinear curve fitting [9] using a single and two Lorentz functions. Comments on the statistical parameters and stability of the fitting procedure see in text.

$\tau_{\text {rot. }}$ Because of noise all investigated $\mathrm{VH}$ contours of AN solutions in IL were processed using a single Lorentz function approach. A certain systematic error estimating HWHH is very likely. Nevertheless this error contributes to all estimations of band parameters of $\mathrm{VH}$ contours, and thus qualitative changes in the rotational dynamics of AN molecules can be deduced.

The main conclusion is that the vibrational relaxation processes are quickened in the IL surrounding. The corresponding correlation times $\left(\tau_{\text {vib }}\right.$, Table 1$)$ decrease from about $3 \mathrm{ps}$ in the neat AN to $1.5-2 \mathrm{ps}$ in AN/IL solutions. The origin of this phenomenon is not yet clear. The IR studies on the isotopically diluted $\mathrm{AN}\left(5 \mathrm{~mol} \% \mathrm{AN}-h_{3} / \mathrm{AN}-d_{3}\right.$, [11]) suggested that the

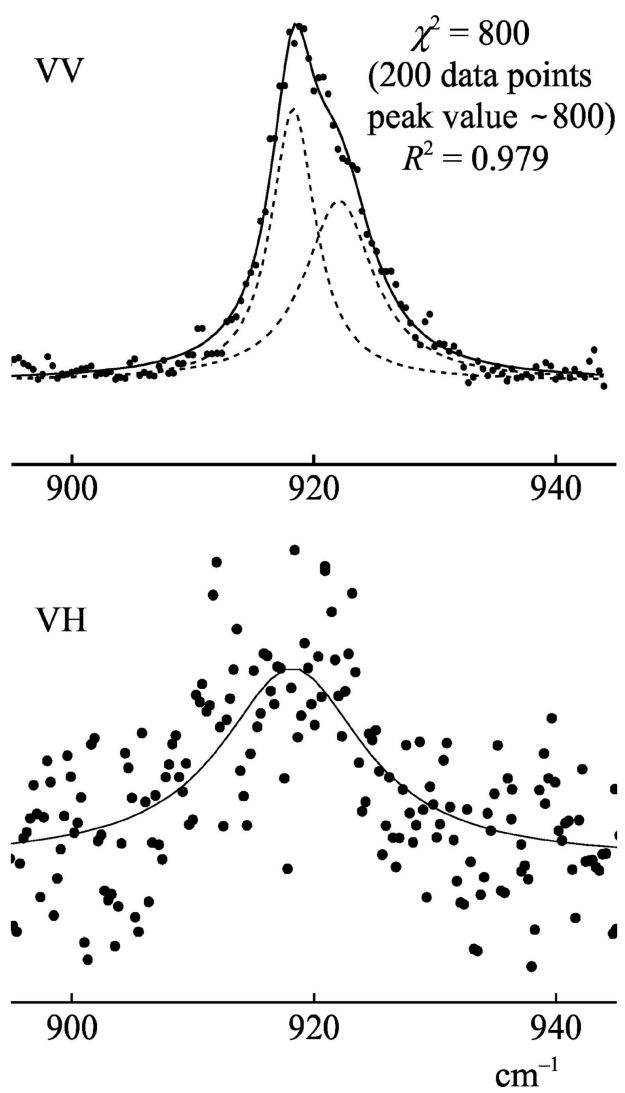

Fig. 5. Raman VV and VH contours of $\nu 4$ mode of AN dissolved in 1-decyl-3-methyl-imidazolium bromide ( $20 \mathrm{wt} \%$ of AN) at $295 \mathrm{~K}$. Other comments see in text.

contribution of the resonance energy transfer is rather small for the AN system. Its contribution to $\nu 2$ was not observed at all. Hence, some new mechanisms, specific to ILs due to their local ionic structuring, which gain the vibrational relaxation processes, may be expected. One of those mechanisms can be the intermode exchange of vibrational energy. This sort of dephasing does not lead to the dissipation of energy from the vibrational subsystem, but only causes its redistribution among additional vibrational degrees of freedom. Quite strong intermolecular interactions of the probe molecule with polyatomic ionic species of IL (in the present case - AN and the cationic part of 1-decyl3-methyl-imidazolium bromide, respectively) can certainly favour this process.

The effect of IL surrounding on the rotational dynamics of AN, namely the tumbling motion of dipole moments is rather small. Although a certain slow-down of AN reorientations in IL can be distinguished, i.e. $\tau_{\text {rot }}$ increases from 1.0-1.5 ps (neat AN) to $1.6-1.9 \mathrm{ps}$ (AN in IL), yet this effect is much less significant than it could be expected for so highly viscous media. For comparison, $\tau_{\text {rot }}$ values up to 2-4 ps were found for AN dissolved in water and water/polymer gels [13]. Such 
drastic slow-down in solvents, the molecules of which possess proton-donor properties, can be understood as a consequence of hydrogen bonding of AN with solvent molecules. In the present case of 1-decyl-3-methylimidazolium bromide it looks that this IL surrounding acts on the rotation of molecular probe as the system being not too 'super-polar'. In other words, considering microscopic friction effects, investigated 1-decyl-3methyl-imidazolium bromide falls in the range between water, which forms huge $\mathrm{H}$-bond networks and still is more polar than most ILs, and AN, where molecular reorientations are hindered by dipole-dipole correlations within small clusters $[14,15]$.

\section{Concluding remarks}

First of all, note that our study on the vibrational and rotational relaxations of AN dissolved in 1-decyl3-methyl-imidazolium bromide has shown that these processes are rather weakly influenced by IL environment. The vibrational relaxation is more significantly enhanced, which is noticeable from about $50 \%$ decrease of vibrational correlation times in IL solution. The tumbling motion of electric dipoles of $\mathrm{AN}$ is much less affected by the IL surrounding in comparison with AN reorientations in water and water/polymeric network systems. One more very important aspect of this study should be noted. The dilution of $10 \mathrm{wt} \%$ was too high for registration of some Raman VH bands, but on the other hand maybe it was too strong with respect to the expected structural peculiarities in IL systems. The demolition of structural effects (short-range order and mesoscopic structuring in the nano-scale) in 1-decyl3-methyl-imidazolium bromide by the mutual penetration of AN and IL species in such a big amount of AN molecules could be suspected. The experimental work carried out in the present study opens the ways for a wider use of this Raman spectroscopy studying fundamental molecular processes in ionic liquids.

\section{Acknowledgements}

This work was supported by the Ministries of Education and Science of Lithuania and Ukraine in the frame of bilateral Lithuanian-Ukrainian research project "Spectrometric monitoring of molecular and molecular-ionic nano-clusters in the liquid state". We are grateful to the Alexander von Humboldt Foundation for support purchasing the laser and ionic liquids.

\section{References}

[1] http://www.merck.de/servlet/PB/menu/ $1014040 /$ index.html .

[2] 92nd Bunsen-Colloquium on Physical Chemistry in Ionic Liquids, Clausthal, 2006: http:// www2. imet.tu-clausthal.de/bunsen92.

[3] D. Bankmann and R. Giernoth, Magnetic resonance spectroscopy in ionic liquids, Prog. Nucl. Magn. Res. Spectrosc. 51, 63-90 (2007).

[4] H. Weingaertner, The static dielectric constant of ionic liquids, Z. Phys. Chem. 220, 1395-1405 (2006).

[5] H. Weingaertner, P. Sasisander, C. Daguenet, P.J. Dyson, I. Krossing, J.M. Slattery, and T. Schubert, The dielectric response of room-temperature ionic liquids: Effect of cation variation, J. Phys. Chem. B 111, 4775-4780 (2007).

[6] W.H. Flygare, Molecular Structure and Dynamics (Prentice-Hall Inc., New Jersey, 1978).

[7] W.A. Steele, in: Vibrational Spectroscopy of Molecular Liquids and Solids, eds. S. Bratos and R.M. Pick, NATO Advanced Study Institutes Ser. B, V. 56 (Plenum Press, New York, 1980), pp. 61-89.

[8] J.E. Griffiths, Molecular reorientational motion in liquid acetonitrile: Raman band shapes, diffusion constants and activation energy of reorientation, J. Chem. Phys. 59, 751-758 (1973).

[9] Origin 6.1, OriginLab Corporation, http://www. OriginLab.com.

[10] F.H. Tukhvatullin, A. Jumabaev, G. Muradov, H.A. Hushvaktov, and A.A. Absanov, Raman spectra of $\mathrm{C} \equiv \mathrm{N}$ vibrations of acetonitrile in aqueous and other solutions. Experimental results and ab initio calculations, J. Raman Spectrosc. 36, 932-937 (2005).

[11] K. Tanabe and J. Hiraishi, Comparative study of Raman and i.r. band widths of acetonitrile, Spectrochim. Acta A 36, 665-671 (1980).

[12] P. Yuan and M. Schwartz, Molecular reorientation in acetonitrile, J. Chem. Soc. Faraday Trans. 86, 593-596 (1990).

[13] U.M. Biermann, W. Mikosch, T. Dorfmüller, and W. Eimer, Comparison of solvent and probe reorientation in polycrylamide gels, J. Phys. Chem. 100, 17051710 (1996).

[14] K. Aidas and V. Balevicius, Proton transfer in H-bond: Possibility of short-range order solvent effect, J. Mol. Liquids 127, 134-138 (2006).

[15] T. Takamuku, M. Tabata, A. Yamaguchi, J. Nishimoto, M. Kumamoto, H. Wakita, and T. Yamaguchi, Liquid structure of acetonitrile-water mixtures by X-ray diffraction and infrared spectroscopy, J. Phys. Chem. B 102, 8880-8888 (1998). 


\title{
ACETONITRILO MOLEKULIŲ, IŠTIRPINTU JONINIUOSE SKYSČIUOSE, VIRPESINĖS IR ROTACINĖS RELAKSACIJOS TYRIMAS TAIKANT RAMANO SKLAIDA
}

\author{
V. Aleksa ${ }^{a}$, V. Barkauskas ${ }^{\text {a }}$, V. Pogorelov ${ }^{b}$, H. Fuess ${ }^{c}$, V. Balevičius ${ }^{\text {a }}$

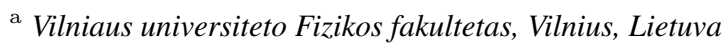

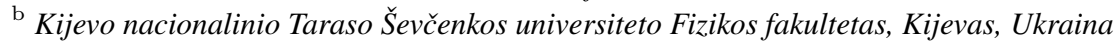 \\ ${ }^{\mathrm{c}}$ Darmštato technikos universitetas, Darmštatas, Vokietija
}

\section{Santrauka}

Joniniai skysčiai (medžiagos, kurios sudarytos išimtinai tik iš anijonų ir katijonų ir kurių lydymosi temperatūra žemesnè nei $+100^{\circ} \mathrm{C}$, toliau - JS) yra vienas naujausių ir sėkmingiausių daugiafunkciniu medžiagu kūrimo proveržių. Savo unikalias savybes JS pademonstravo ivvairiose aukštųjų technologijų srityse, iš kurių ypač paminètinos enzimų katalizè, proteinų sintezè, membranų technologijos, kuro celès, dažalais pajautrintos Saulès baterijos (DSSC), dujų jutikliai, nanostruktūrizavimas ir kt. Milžiniškame darbų ir publikacijų sraute aptinkamos kai kurios labai svarbių tyrimų spragos: pavyzdžiui, labai mažai duomenų paskelbta apie fundamentaliuosius molekulinius vyksmus, tokius kaip virpesinè ir rotacinè relaksacijos, protono pernaša, konformaciniai virsmai ir kt.

Šiame darbe virpesinès ir rotacinès relaksacijų tyrimams i JS terpę buvo implantuojamos simetrinio vilkelio tipo bandomosios molekulinès sistemos (molekuliniai zondai). Buvo tirti acetonitrilo $\left(\mathrm{CH}_{3} \mathrm{CN}\right.$, AN) molekulių 1-decyl-3-metil-imidazolio bromido (aha2 / cdi16) terpejje Ramano spektrai, keičiant AN koncentraciją ir temperatūrą. Informacija apie virpesinę ir reorientacinę dinamiką buvo gaunama analizuojant AN molekulių Ramano sklaidos spektrinių smailių ties 918 ir $2249 \mathrm{~cm}^{-1}$ (literatūroje žymimų atitinkamai $\nu 4$ ir $\nu 2$ ) formas, užregistruotas naudojant ivvairias žadinančios ir išsklaidytos šviesos poliarizacijų kombinacijas. Virpesinès ir rotacinès relaksacijų koreliacijų trukmès apskaičiuojamos pagal formules $\tau_{\mathrm{vib}}=1 /\left(2 \pi c \Delta_{\text {iso }}\right)$ ir $\tau_{\text {rot }}=1 /\left[2 \pi c\left(\Delta_{\text {anis }}-\Delta_{\text {iso }}\right)\right]$, čia $\Delta_{\text {iso }}$ ir $\Delta_{\text {anis }}$ yra atitinkamai izotropinių ir anizotropiniu juostu puspločiai, kurie buvo ìvertinami ištyrus VV ir VH smailiu formas. Nustatyta, kad AN molekulių virpesinè relaksacija paspartèja nuo 3 ps grynajame AN iki 1,5-2 ps AN/JS tirpale, esant 10 ir 20 sv. \% AN koncentracijai. Rotacinė relaksacija sulètėja nežymiai - nuo 1,0-1,5 ps (AN) iki 1,6-1,9 ps (AN/JS). Gautieji duomenys aptariami tarpmodinès energijos pernašos, klampos, tarpmolekulinių vandeniliniu ryšių formavimosi, struktūrinių bei dielektrinių JS ypatumų mechanizmais. 